\title{
Paradoxes of Anti-austerity Protest: Matters of Neoliberalism, Gender, and Subjectivity in a Case of Collective Resignation
}

\author{
Magnus Granberg* and Katarina Giritli Nygren
}

This article analyses an episode of collective resignation. Carried out mainly by specialist nurses, this is a proliferating form of worker protest in Sweden that poses a challenge to austerity policy and emerges in a specific industrial-relations context. Mobilizing for collective resignation, activist nurses navigate terrains of neoliberal governance, marketization and flexible labour-market dynamics. The collective resignation is also a form of action underpinned by a discourse of gender equality. Our analysis, which attends to the co-emergence of gendering and subject formation in the narratives of a group of activists and to the use of gender-equality rhetoric in framing collective action, shows how opportunities for collective action arise that also restrain the exercise of agency. In this case, subject formation included contrasting nursing to tropes of archetypical militant workers and negotiating tensions between care and collective action. This involved reproducing and challenging established forms of gendering.

Keywords: collective action, gender, neoliberalism, nursing, subjectivity

\section{Introduction}

$\mathrm{T}$ his article explores the gendering effects of labour conflict as new forms of collective action emerge in contexts shaped by neoliberal restructuring; we attend to how gendered images of worker resistance and of nursing are deployed in narratives of an episode of collective resignation. The recent phenomenon of collective resignations, we argue, may be understood as a distinctively neoliberal form of worker action because it rests on the aggregation of individual decisions, and not on a single collective decision as in the traditional strike ballot. Not only is this form of labour conflict facilitated by neoliberal restructuring, it also disrupts the meaning of collective action. In Sweden, collective resignations tend to be limited in range, organized independently of unions at the workplace level; we will explain how these actions provide an outlet for grievances, including gender inequality, that are muted in the system of collective bargaining. Thus, we ask: what latitude is there for collective action in neoliberal austerity regimes? What happens when activism is subjected to imperatives of individualization? How does subject formation in activist storytelling relate to the rhetoric of gender equality and the gendering of the nursing profession?

Our premise is that labour conflicts are marked by gender, while at the same time they also do gender; they have gendering effects. Briskin (2007a) tries to capture these dynamics using the notion of 'gendering militancy', in which gender is seen to be mobilized, resisted and transformed in the course of labour conflicts, which are in turn shaped by these gendering practices. Briskin is particularly concerned with women's labour militancy and the dialectic of occupational gender segregation and gendered modes of labour struggle. In contemporary public services these processes intersect with

Address for correspondence: *Magnus Granberg, Department of Social Science, Mid Sweden University, Holmgatan 10, 87150,

Sundsvall, Sweden; e-mail: magnus.granberg@miun.se 
'austerity' policies and processes of commodification and, as we will suggest, this affects the form worker action takes and what we refer to as subject formation - the framing of conflict and the fostering of collective identity.

As Briskin (2013) has shown, collective actions by nurses have often involved resignations rather than strikes, reached out to wider collectives and negotiated gendered images of the profession (e.g. Henttonen et al., 2013). In this article, we focus on how processes of commodification enable and shape nurses' collective actions, seen as part of a wider fightback against crisis-related austerity by public workers (Colatrella, 2011; Gall, 2012). As Briskin shows, women's labour militancies connect to the ways in which worker power is distributed across industries and sectors in capitalist society; importantly, most public workers do not produce commodities, so their strikes do not cause direct financial losses. However, neoliberal transformations of the public services may change this - 'commodified healthcare' (Kavendy, 1999) is a case in point. Purchaser-provider schemes and specialization within the public sector introduce commodification in services that remain publicly funded, indirectly empowering certain groups of public workers. However, their taking on of such 'structural power' (Silver, 2003) does not obviate the necessity to frame conflict and develop collective identity.

We will explore the gendering effects of collective action in a context of commodification and austerity; collective resignations are carried out by structurally empowered nurses against what they see as deteriorating working conditions. In the following sections we explain the context of collective resignations and outline some theoretical points of departure. Then we discuss the case study and analytical strategies. Our analysis begins by exploring opportunities for collective action in specialized nursing that arise under neoliberalism, and then moves to consider subject formation and the uses of gender-equality rhetoric in activist narrative. Conclusions are discussed in the final section.

\section{Austerity, healthcare restructuring and industrial relations in Sweden}

The collective resignation, in its contemporary form, emerges in a context of austerity during Sweden's crisis-related neoliberal turn. Although the nurses' union organized a nationwide campaign for collective resignation in 1951 (Bohm, 1961), collective resignations emerged in earnest during and in the years following the economic crisis of the 1990s. Reaching a peak toward the end of that decade, they fell back as staff levels and conditions improved in the early years of the new millennium; however, with the onset of a new phase of austerity after the global financial crisis collective resignations again increased rapidly (Granberg, 2016). Since the 1990s, public workers have faced austerity and new public management (NPM) reform (Larsson et al., 2012). Working conditions in care services are hit hard (Hertting et al., 2005), but among these mainly female groups of workers only specialized registered nurses (and midwives) have sustained high levels of local mobilization, seen most vividly in collective resignations.

The nurses' union (the Swedish Association of Health Professionals) and the municipal workers' union have conducted several strikes since the 1990s and often framed such actions in terms of protecting the public interest. This militant stance by the unions - who are not prone to militancy per se - exerts pressure from aggrieved (mostly female) members who feel exploited and unfairly remunerated, and are suffering from speed-up and high rates of work-related illness (Hertting et al., 2004; Selberg, 2012).

The emerging field of commodified health care and the Swedish industrial-relations system imposes structures of opportunity that shape collective resignations. As noted in the introduction, the implementation of purchaser-provider schemes introduces commodification in public services. While Sweden's healthcare system remains publicly funded in most respects, organizational restructuring has brought the creation of a network of specialized wards and departments. Importantly, counties who are responsible for the provision of health care pay each other whenever patients require services that are performed outside their county of residence. Workers in such enclaves of specialized health care thereby assume what Silver (2003) calls structural power: an ability to cause major financial losses, akin to workers in manufacturing, should they strike or otherwise withhold their labour. 
Our analysis will attend to the specific mechanisms involved here with regard to collective resignations, e.g. the nursing shortage.

The industrial-relations system has profound effects on collective resignation. It should be noted that Sweden historically exhibited extraordinary levels of illegal or 'wildcat' strikes during the postwar decades, especially in the turbulent 1970s and 1980s (Korpi, 1981; Thörnqvist, 1994). Some of these strikes were canonized and became part of collective memory, at the expense of strikes by women workers (cf. Schmitz, 2007); as we will see later on, this affects militant workers' self-perceptions. Like wildcats, collective resignations occur because the right to strike is severely circumscribed and because unions are centralized to an extent that they become virtually out of touch with their membership. To conduct collective resignation on a union basis is illegal. Rank-and-file discontent with the last couple of union-led strikes caused many to consider the union irrelevant as a lever to improve conditions. To wildcat is not an option for local nurses, however, as it is hard to ensure patient safety in the manner of a controlled strike. Moreover, while there has been devolution of bargaining to the workplace level, this is not the case with the right to strike - which is still the prerogative of the national union leadership. However, the devolution of bargaining to local units, even down to individual employees, affords an incentive to carry out individual or collective resignations as a threat or protest act. All in all, these nurses will seldom turn to their union (and if they do, they will consult local chapters for legal guidance), meaning that their actions are almost always local affairs taking place within a single ward (cf. Granberg, 2016).

\section{Feminism, mobilization and collective resignation}

Collective resignations by Swedish nurses are relevant to debates on labour struggle and gender equality. The last decade has seen lively discussions on 'the future of feminism'. While some scholars emphasize obstacles in the contemporary social landscape (Eisenstein, 2009; Fraser, 2009; McRobbie, 2009), others stress new opportunities and associated transformations of feminist activism (Walby, 2011). In the latter vein, researchers point to how new spaces for feminist politics arise as it intersects with labour activism (Franzway and Fonow, 2011) and is displaced onto neoliberal social terrain (Newman, 2012). This would seem to apply quite well to the nursing profession.

As a predominantly female profession increasingly involved in labour conflict in advanced capitalism since the 1980s, nursing epitomizes a trend Briskin (2007a) calls the feminization strike activity a trend related to the 'tertiarization' (Bordogna and Cella, 2002) or migration of strikes from manufacturing to the service industries in recent decades. Briskin (2007b) argues that not only are strikers increasingly likely to be women but the issues raised in labour conflict are increasingly likely to concern gender equality. However, the fact that this opportunity exists does not ensure the articulation of feminist politics. Labour struggle may challenge established forms of gendering because mobilization and collective action unsettle accepted notions of what constitutes work in a certain field what it demands of workers, its values and imperatives - making labour struggle a contingent affair. But this open-endedness also means that gender equality is only one of its possible modes of articulation (Franzway and Fonow, 2011).

This is how we understand Briskin's thesis (2013) that nurses' strikes involve 'politicization of caring', a form of labour militancy that entails framing collective action as patient advocacy through a set of practices that challenges established forms of gendering. Research thus testifies to a tendency of nurses to portray strikes as patient advocacy (e.g. Brown et al., 2006), matched by a tendency of nurses' antagonists to claim that striking is incompatible with caring (e.g. Bessant, 1992). This puts labour conflict at the centre of what scholars have identified as a key aspect of the gendering of nursing: the 'virtue script' (Gordon and Nelson, 2006), the idea that virtue is its own reward; an entanglement of femininity and care, the origins of which date back to the religious idea of a 'higher calling'. On the one hand, politicization has been noted to dissolve oppositions between doing right by oneself and attending to the needs of others, expand the scope of care and merge struggles for gender equality with advancing the public interest. However, politicization has also been noted to be used against 
charges of irresponsibility as nurses try to win the support of co-workers and/or the general public (cf. Granberg, 2014; Briskin, 2013).

When there is a trade-off between politicization and gender equality, the appropriation of elements of the virtue script (nurses fighting/martyring themselves for patients) may be seen as aligning goals with an established gender framework. In order to explain this, labour conflict can be considered a form of social movement that involves a process of mobilization (cf. Kelly, 1998). Mobilization pivots on the ability of members of a collective to agree on their interests, which might concern gender equality, quality of care or working conditions, for instance. Interests are a key part of collective identity. Mobilization also involves processes of framing; that is, ways of representing issues of conflict. Relatedly, Einwohner et al. (2000) state that gender can be used by as well as against, to legitimize and delegitimize movements, in processes dependent on wider discursive contexts. Here, frames consistent with existing beliefs and practices can be more successful than ones that challenge them; it can thus be more effective in the short term to align movements with established gender frameworks (Einwohner et al., 2000). When making strategic decisions 'activists', or the individuals at the forefront of mobilization, may then opt not to define interests in terms of gender equality.

Matters of interest articulation and framing are especially acute in collective resignations because this form of worker action relies on aggregating individual decisions rather than a collective one that instantaneously aggregates, as in a strike ballot. It is important to note that the collective resignation does not necessarily entail an intention of actually quitting; rather, it involves a threat that nurses hope will make the employer concede to their demands. As a form of action based on aggregating individual actions, it is vulnerable even to minor levels of intra-group division and hinges on almost complete participation: nurses bent on following through on the threat run the risk of having to leave their jobs if the employer is not forced to back down. Furthermore, every form of collective action exploits 'structures of opportunity' (Kelly, 1998, p. 37). In this case, such structures include the specifics of Swedish industrial relations and the introduction of neoliberal reforms in the national healthcare system. Thus collective resignations emerge as the main form of opposition to austerity in this area of working life, something we will attend to in the following section.

\section{Case study and methodology}

Around the time of data collection, newspapers reported 17 episodes of collective resignation by registered nurses or midwives in Sweden (Granberg, 2016). Sampling partly reflected logistical concerns, but also theoretical ones. The episode analysed here was atypical (Emmel, 2013): while collective resignation will, in most cases, involve a majority of nurses employed in a hospital department vowing to resign, here only one-third handed in their notice. The episode was sampled to capture intra-group disagreement on the course of action since this was assumed to expose negotiations on ideas of nursing and the rationale of collective action. In terms of the present analysis, the case represents a challenging context for 'activists' (discussed subsequently), who had to work hard to legitimize collective action and thus drum up support within the nursing collective. Twelve interviews, making up about one-third of the workforce, were held within six months of the resignations coming into effect, with nurses (all in non-management positions) who threatened to quit and ones who did not. Interviews lasting between 60 and 100 minutes were conducted, recorded and transcribed.

Interviews were unstructured, beginning with questions such as 'Can you tell me about the recent conflict on the ward?'. This elicited renditions of events that transpired in the course of the dispute; sometimes chronological, sometimes not. Mostly, informants gave a background of worsening conditions then moved on to particular events. Interviewees spontaneously reflected on more general questions, such as values in nursing, recent strikes by the nurses' union, its place in the labour movement, etc. Subsequent questions were confined to following up events and themes raised by participants. In this narrative method researcher and informant thus co-construct an account (Riessman, 2008).

Informants spoke of a range of grievances related to staffing, scheduling, speed-up, on-the-job education and pay. Virtually all registered nurses on the ward took part in efforts to force a raise, but that does not mean pay was their main concern; pay is linked to the ability to attract new staff, 
hence to the intensity of work and grievances such as stress. Enforcing higher wages, many nurses thought, would correct an injustice concerning low pay and improve other working conditions. This was not a far-fetched idea: nursing student organizations employ tactics of discouraging new nurses from taking relatively poorly paid jobs - a quite effective strategy in this part of the country. (Incidentally these tactics are illegal when applied by trade unions, so student organizations have assumed what was once a union role.) However, as our analysis will show, interest articulation and framing was in flux throughout the dispute and hence also the understanding of demands, reflecting the open-ended nature of collective action. After some informal meetings, corridor talk, e-mail exchanges and petitions to management, the conflict escalated and talk of resignation began. Divisions among the nurses arose as some considered this route too extreme. Only one-third handed in their notice.

Despite management consenting to a county-wide raise, most who threatened to resign followed through, reflecting how this form of action co-emerges with individual strategies of moving between jobs - collective resignations coordinate individual acts. By the time management caved in, most had made other arrangements. However, as this analysis shows, decisions to leave also related to how nurses interpreted the outcome of collective action.

This analysis uses pseudonyms to ensure confidentiality and focuses on the role of activists in shaping how collective action is articulated, or how subject formation is accomplished in an open-ended process. We consider those informants who render themselves as promoters of collective action to be activists, comprising eight of our interviewees. However, as a rationale for using interview excerpts, we will attend to segments of argument that are deemed essential to the process of collective subject formation, meaning that we hone in on a smaller number of activists' narratives. Activists, it should be noted, faced some internal opposition as well as dejection: the case brings out the challenges and pressures activists may face in rallying for collective action. Focusing on the activists is intended to bring into relief the process of articulation and the agency involved here. We consider other informants' accounts to the extent that they contextualize activists' narratives. In order to analyse the co-emergence of gendering and subject formation in activist storytelling, we inspect how a story of collective action - of this specific, localized labour conflict - intersects a non-localized, global narrative on the history of nursing. The story intersects the narrative at certain 'turning points' (Riessman, 2002, pp. 705-6); radical shifts in the expected course of events, which, according to Riessman, alter the meaning of past experience and hence subject formation. In this case, turning points in the localized story induce changes in the global narrative.

Our analysis is based on three strategies. First, we analyse how opportunities for collective action by specialist registered nurses arise as Swedish health care undergoes NPM reform. Here, we focus on the institutional and sectoral features within this emergent healthcare economy that facilitate collective resignations. This means reading interviews as windows into processes that exceed the narratives and the process of subject formation; windows into the environmental features of specialized and commodified health services, which form the opportunity structures shaping collective resignations.

In considering subject formation - the second strategy — we found it most fruitful to view collective action as self-generative and undetermined. Our strategy takes its cue from analyses stressing the open-ended articulation of subjectivities in labour conflicts (e.g. Fantasia, 1988). Hence interests and demands change as collective action unfolds. The latter 'posits its own presuppositions' (Hegel, 2010, p. 489); while not immune to outside influence, there is more than a little causa sui to it. Collective action is no teleology, but once it is framed in certain ways and once interests are defined, this shapes its future articulation. Further, activists must negotiate a minefield of accepted professional values and what they take as subjective preconditions of mobilization; that is, activism is founded on assessments of how far a group can be pushed into confronting their employer and of what arguments the group is responsive to. In doing this strategic work, activists run the risk of reproducing gendered presumptions relating to their perception of the radicalism or militancy of the group. This perception will probably change as collective action unfolds, which exerts positive or negative feedback on 
mobilization (Biggs, 2003). We thus attend to activist narrative as speaking to this semi-autonomous articulation of collective action.

The third strategy is to explore how gender-equality rhetoric is deployed and displaced as activists frame conflict and articulate interests. The second strategy is helpful in this regard: exploring the selfgenerative and open-ended articulation of collective action involves investigating how certain kinds of articulation are broached only to be discarded at a later stage. Along with the first and second strategies, this will enable us to assess the gendering effects of this episode of collective action.

\section{Analysis}

Our analysis consists of two parts. First, we look at collective action in context: information given by the interviewees indicates how opportunities for collective action arise from healthcare restructuring, including the increasing flexibility of labour markets and the commodification of health services. Second, we look at turning points in the account of collective action: a gendered narrative on the history of nursing intersects a story of local conflict to produce a subjectivity; thereby, we also inspect how gender-equality rhetoric is deployed.

\section{Collective resignation in context}

Activists felt that nursing was at a crossroads. The local conflict was seen in terms of a general worsening of working conditions and the quality of service. One participant referred to 'the end of the people's home' (folkhemmet), a concept signifying the postwar expansion of welfare services. 'This conflict is just a small part of the much larger problem and that's cutbacks on health care [...] that's why there's so much ... um ... polarization these days' (Ida). New ways of thinking about public services came with austerity, according to Ida: 'nowadays it's all about money; in schools, in elder care, and in the hospitals'. Not only did activists explain the context of the conflict by referencing neoliberalism, cutbacks on funding and invasive economic rationality; they also identified related opportunities making collective action possible. One such feature was how the nursing shortages (Oulton, 2006) are exacerbated by increased labour-market flexibility. Shortages are particularly severe among specialist nurses and midwives, putting these groups in a relatively strong position: 'specialist nurses with lots of experience are irreplaceable [...] other employers are delighted to get competent staff, competent nurses' (Pia). Temporary employment agencies have of late made inroads into Swedish healthcare services, first by supplying doctors and now also registered nurses. Some nurses used agencies to secure alternative jobs in case management would not give in. Labour-market flexibility, in conjunction with nursing shortages, thus facilitates collective resignations.

Another facilitator is differentials regarding pay and working conditions between Sweden and neighbouring Norway. Although not an EU member state, Norway permits Swedish citizens to work in the country indefinitely. Employers pay higher wages while also facing nursing shortages. Norway provides an important alternative source of employment for specialist nurses in Sweden. One informant expressly related collective resignations to this:

We can't make any other kind of threat besides saying that if we don't get this then we're not going to work here anymore [...] we wouldn't be able to do so if it wasn't for the possibility of getting work in Norway. (Fia)

Indeed, three participants who quit the ward reported they were now commuting to Norway.

Moreover, the introduction of purchaser-provider schemes has strengthened nurses when engaging in the kind of brinksmanship that collective resignation entails, partly by inducing employers to compete for personnel, but also because they enable nurses in key areas of commodified health services to hurt employers financially. Because wards in major hospitals' service regions span several counties, stoppages or reductions in their capacity to admit patients, as Pia explained, are financially detrimental: 'that inter-county money, as they say, now accrues to other counties and that costs millions'. 
However, reflecting that opportunity structures both enable and constrain collective action, threatening to quit is not nurses' weapon of choice; as Fia explained, 'it's our only weapon':

We're loyal to the patients, that's the bottom line. As long as patients don't come to any harm; we want to hurt the county as much as possible, but patients can't be allowed to come to any harm, so we really don't have any other option. (Fia)

Referring to wildcats, she said: 'there's no nurse in the world, well, no person at all, who would sit down and watch the patients die'. Because these strikes are illegal and not union-led, they would have to be local occurrences and thus hard to conduct in the manner of a controlled strike that ensures patient safety. In contrast, threatening to resign is legal and grants employers respite. However, the decision to take action then resides with individuals, not the collective. Swedish labour scholars (Fransson and Thörnqvist, 2003) call this 'collective individualization', a coordinated but individually pursued action.

\section{Turning point 1: an accommodating profession becomes militant}

Describing the background to the conflict and its culmination in threatening to resign, interviewees listed a number of grievances: speed-up caused by reduced nurse-to-patient ratios; deprofessionalization due to new managerial prerogatives and cutbacks on education, training and planning; more irregular hours due to scheduling changes; and relatively poor wages given the level of education and experience required. Besides positing grievances in a frame of neoliberalism, activists also used the frame of gender inequality:

Really it all started with the original nurse, this Florence character, who considered caring her calling and didn't mind about wages. Today, even the specialized nursing professionals with lots of experience - we still have to fight this woman's ... this idea that we're in a woman's line of work [...] This is one reason conditions are so bad. (Fia)

The background was thus explained in terms of inequality based on gender discrimination. This also applied to an event activists viewed as a catalyst: staff were taken on at higher wages than nurses who had more than 20 years' experience on the ward. Activists spoke favourably of better entry-level wages, applauding campaigns by student organizations to this effect. What caused anger was the gender implications of recruiting: a male nurse was taken on at better pay than any registered nurse on the ward. Activists saw this as reflecting male privilege in a 'female' profession (cf. Williams, 1992): 'here comes this guy, no surprise [laughs], and gets a super salary. Had he been a woman it wouldn't have been the same, she'd have no special treatment' (Ann).

It should be emphasized here that most activists spoke of this as a catalyst, not only for their own sense of indignation but for the general sense of indignation in the collective at large, and hence as a defining moment in the mobilization. A turning point.

At this stage, we call attention to the salience of gender equality rhetoric - in the story of the local conflict and in the narrative of nursing. Considering collective action as an open articulation whose final expression is undetermined, gender equality can be understood as one of the possible emphases that collective action entailed at this stage. Although not explicitly feminist, it was deployed in a variety of ways. Relying on this rhetoric, activists defined interests in terms of gender equality and framed collective action as advancing women's social position: 'women aren't taking this bullshit any more' (Fia).

To repeat, this marked the first turning point in the story; the point where the mobilization proper began. The catalyst is identified with the hiring of a male nurse at an undeservedly high wage. At this stage, momentum grew rapidly. Mia felt it was a crucial transformation, although she said it was hard to put into words:

It was a great feeling [...] we all came together as one [...] I felt the dynamic changing on the ward. The other professions felt it too; I mean that everything had changed, that something fundamental had taken place ... There was a unity, a fighting spirit, and a commitment. (Mia) 
This also marked a turning point in the narrative on nursing. As seen in Fia's earlier remark, this narrative starts with the figure of an accommodating, non-militant 'Florence character'. Ida thus saw the history of nurses' strikes and union campaigns in Sweden as deplorably timid: 'I'm talking about the entire profession now and there's been very little resistance on our part, very few strikes and protests'. Accommodating nurse attitudes had been exploited by employers until this day: 'they've taken advantage of this for so long, this Florence Nightingale; that nurses love their jobs and sacrifice for patients'. For Pia, attending the strike meetings with her father during the famous 1969-70 miners' strike - where 'the lads decided on everything, like "let's take a vote! Yes or no?", and took a show of hands' - served as a contrast to the nurses' strike in 2008, in which she thought the union had betrayed its membership.

This kind of comparison was often used by activists and established a gender dichotomy between strike-prone industrial workers and docile nurses. It is based on the trope of the militant subject of male manufacturing workers and refers back to the postwar revival of labour conflict in the 1970s. The wildcats of that decade are probably the most well-remembered in Swedish popular history. However, recollection is not without its gender politics. Emblematic strikes occurred among dockers (1969), miners (1969-70) and forestry workers (1975), all predominantly male lines of work; but less well-known strikes and occupations by women workers also took place, among cleaners (1974-75) and textile workers (1981), for instance. The latter receive scant attention (Schmitz, 2007). An image of the male militant has been established, blocking the memory of women's (including nurses') labour militancies.

In contrast to this militant subject, the female non-militant nurse is portrayed as essentially accommodating. In Fia's words, 'this is a woman's job and it's been that way forever. There's no ... there's no man who would put up with the conditions we've got'. Contrasting nurses to militant industrial workers at the nearby auto plant, Fia said the nurses' working conditions 'would not be tenable with male workers. It's a shame us women are like that [...] that we're such an accepting sex'. The characteristics of this image of nurses acquiescing to exploitation and cutbacks was also conveyed by contrasting it to predominantly male miners, 'who know their rights, who can say no [...] who are not afraid to say no' (Mia). Activists called on fellow nurses to 'stand up straight' (Ida) and be more 'gutsy' (Mia) - imperatives evocative of the image of the contentious male worker.

However, the fundamental shift taking place locally, that 'great feeling' of which Mia spoke, was reflected in an analogous shift on the global level, with nursing moving away from its old submissive stance. Activists described this as a generational shift: 'there's a new generation entering health care and they're not letting themselves be trampled on like older generations of women' (Ida). Ann remarked:

There's been many let-downs, it's been like 'yeah, let's do this!' but then it's like 'oh well, maybe next time around' [referring to bargaining rounds]. That's why we have to put up with lousy conditions. But now, I really think this is changing. (Ann)

\section{Turning point 2: setbacks and lingering docility}

At this stage the readiness to act collectively was put to the test. Story and narrative alike take a radically different turn. As we will show, this had important effects on the articulation of collective action in terms of gender equality; similarly, the nature of 'collective' action was fundamentally questioned. The shift is marked by a reassessment on activists' part of the attitudes of their co-workers and of nurses in general, as subjective preconditions to mobilization on matters of labour militancy.

Several processes converged to break the momentum. As nurses turned to the local media to voice demands and concerns over the long-term erosion of the quality of care, management called nurses to individual hearings, asking if they agreed with the bleak image painted in the press, claiming that activists tarnished the ward's reputation. This move was part of a strategy of divide and rule aimed at the nursing collective on the ward, as reflected by the decision to split the ward in two after the conflict abated. It is also likely that management sought to undercut solidarity among close colleagues at the hospital; at least, its insistence on funding better wages on the ward by drawing on funds from 
nearby departments suggests this. In a word, management engaged in 'counter-mobilization' (Kelly, 1998, pp. 25-26). As push came to shove activists were only able to rally a minority behind the threat to resign.

Activists displayed mixed feelings about the fact that many nurses on the ward did not join the resignation. They recognized that not everyone would be ready to put their jobs on the line because of personal circumstances; yet it is also clear that they did not think this an entirely valid argument, since reneging on the threat was always an option given the nursing shortage. As Fia puts it:

It's a shame not everyone resigned. Because then they would have been forced to back down [...] It was very unfortunate and although I can see that not everyone feels that they can make this threat, I still think that they should have. They would have been able to keep their jobs anyway [...] It's not like the county could do without them; that's impossible, and we really ought to know this by now. (Fia)

Indeed, some nurses who handed in their notice retracted, kept their jobs and got the raise. In one sense this testifies to opportunities opened up by the nursing shortage and NPM reform - but it also speaks to the constraints the same opportunities impose. While a threat to resign does not have to be acted on, the gravity of handing in one's notice is still considerable. Decision rests with the individual rather than the collective, hence unity cannot be ensured. Mia, who spoke on nurses' behalf to the press, explained that 'there was no pressure on those who did not want to hand in their notice'. Although only one interviewee openly sided against resignation, such opinions troubled nurses who wavered on whether or not to hand in their notice. As a nurse who did not choose to resign said: 'if I go along with this, I better hope everyone does the same, because I don't want to leave' (Sue). Further, this restricted interest articulation and the framing of collective action as activists tried their best not to alienate anyone:

It got very intense, especially after it hit the media, which happened at a pretty early stage. It was hard, it was very difficult ... having to deliver a message [...] although I'm speaking for a group, it's still me who says the words, who defines how they think. What I was most afraid of was that I was going to say something that they didn't agree with. (Mia)

Mia stressed the 'risk of coming across as if we were making unreasonable demands, as rabid women who didn't know our place'. It seems this risk mainly concerned the reaction of colleagues, not public opinion. At this stage in activists' accounts, talk of gender equality fades away while they relay how a search ensued for common denominators in order to drum up support for joint collective action. So, rather than striking a blow against systemic gender inequality in care services, focus shifted to wages and the need to improve staffing on the ward. Here, it is important to remember what interviewees related about this strategy in the section on the case study: nurses assumed that relative wages on the ward, compared to county wages, affected the ability to recruit staff. In short, the problem was not the employer's reluctance to take on new staff — the ward was hiring constantly, interviewees said - but its policy of keeping wages low, especially as student nurses coordinated to freeze out workplaces with sub-average conditions. This new way of articulating collective action resembles the politicization of caring: in order to maintain quality of care, working conditions and staffing must be improved (e.g. Brown et al., 2006; Briskin, 2013).

This change in how collective action was articulated thus involved relying on an ethics and rhetoric of care: collective action was increasingly framed as a caring act, as in a form of patient advocacy. The rudiments of this novel framework are borne out by Pia's remark: 'it's important to recognize that the working conditions are insane. They are hazardous to patients, who don't get the quality of care they are entitled to'. Explaining what the resignation campaign was meant to accomplish, she said 'we hoped that it would improve quality of care, because we could see that we didn't have time to do our jobs properly'. Or, as Ann puts it: 'to be able to do good, we also have to do right by ourselves, or we'll just wear ourselves out - and then who will do good?' These arguments correspond to what has been called the politicization of caring, and research shows this challenges some established forms of gendering. We do not dispute this, but we observe that, on this 
occasion, politicization ensues as activists retreat from concerns with gender equality to deflect criticism of collective action.

At this point in their account activists deplored the conservative sentiments of 'diehards' (Ann), who had sided against collective resignation on moral grounds, invoking patients' rights. Thus this phase coincided with a turning point in the global, non-localized narrative on nursing. Earlier, emphasis was on how new generations of nurses discarded the prejudices characteristic of earlier generations of 'women' and looked at their jobs in a more sober light; however, now emphasis shifted to lingering forms of docility. This is borne out by the following comment:

If you compare us to people working in the mines up north [...] no one depends on them except their company ... we've got this third party and this third party is being used against us, and that's where it comes in, this vocational thinking. I think our do-gooder issues are connected to this in the sense that it used to be a calling, a higher calling [...] now you are 'productive', a self-effacing dogooder. (Mia)

\section{Turning point 3: an unsatisfactory outcome}

This turning point occurs as the outcome of collective action materializes: management offers a raise and nurses who had handed in their notice respond. Unlike prior bargaining rounds this raise was substantial. One informant said it was some five times that offered in prior rounds. Moreover, it applied to all nurses in this specialization in the county, not just those on the ward. Yet activists viewed it as insufficient to remedy understaffing; most who vowed to quit made good on this. However, many were pleased to have pressured management to concede: 'it was a partial victory. If we'd let the union bargain for us, we'd never gotten this raise' (Ida). Dissatisfaction with the result stemmed from the disappointment of hopes raised during collective action. Activists hoped to raise the assertiveness of the collective. Although this had indeed happened to some extent, nurses who left feared that those who remained would not keep the struggle going:

I really hope that those who are left continue to push for change, that they're able to do something about the problems with working hours, schedules, work environment, and wages. They didn't risk anything, you know [...] It's hard to know what they really think. Sure, they're happy about the raise, they're thankful all right. We did the job, we left, but those who've returned ... One of us who withdrew her resignation told me she got told to keep a low profile now that she's going back with her tail between her legs. It's terrible, the attitude of some of the diehards back there. (Ann)

In terms of the narrative on nursing, activists assessed that nursing was still at a crossroads between archaic but tenacious ideas of self-sacrifice and a more assertive, maybe even militant identity:

In some ways the calling is still around, because the job is still more important than anything else and we push ourselves way too far sometimes [...] I just hope that people will rate themselves more highly [...] I hope that the new generation of nurses will make up their minds and say 'this is my job, nothing more and nothing less, and I want my rights'. (Mia)

This is the subject of contemporary nursing as told by activists, and it is one that they ultimately felt they had to abide by. Activists initially had rather bleak views of their profession's ability to look out for itself:

The reason I got so involved is that resistance has been so rare, but now there was this entire group of nurses who were actually doing something [...] it seemed they were really ready to act and I though 'gosh, they actually mean it this time'. (Ida)

When this united front began to crack, activists rapidly gave up on putting the decision to resign to a vote (this transformation of decision-making has occurred elsewhere in collective resignations) and focused on organizing individuals who had volunteered to resign. Although there is no way to second-guess activists' assessment of the situation, the disheartening image of nursing that eventually 
crystallized certainly did not warrant pushing the limits of mobilization; in this sense, the image almost appears self-fulfilling.

A consequence of activists' strategic decisions was that the initially prominent issue of gender inequality - which had sparked the conflict - was pushed to the back burner. Evaluating the result of the conflict, activists did not return to initial complaints about the devalued status of 'women's work'. While the articulation of collective action created its own conditions, patient advocacy assumed centre stage along with wages and staffing. This explains a remarkable feature of activists' evaluation of the outcome: the exceptional raise in county-wide wages was a cause for disappointment, as the wholesale nature of the raise hindered rather than helped recruiting. As Ann explained, 'when they raised wages across the board, it meant we weren't likely to see any changes in the number of applicants to our specialist training programme'.

\section{Conclusions}

In this analysis we first explored the opportunities for collective action by specialist nurses that arise from healthcare restructuring: facilitators involving the nursing shortages, the increased flexibility of labour markets for nurses and commodification. Then, this case of collective resignation was analysed by its gendering effects. Focusing on subject formation as a story of local conflict intersects a narrative on nursing, and we saw that formulating a 'contentious' nursing subjectivity involved contrasting the tropes of a militant subject and a docile nurse. Such docility was understood to determine nurses' propensity to act collectively. At the descriptive level, informants repeated assumptions that women are poor at acting collectively to assert their interests - assumptions fostered by an imaginary history of militancy that denies the memory of strikes by women. At the same time, nursing was described as moving away from docile attitudes, a view framed in terms of the improvement of women's social position and expressed in gender-equality rhetoric. Furthermore, at the level of (tacit) practice, the mobilization on the ward and its confrontational tactics challenged the virtue script in nursing (Gordon and Nelson, 2006). In the end it resulted in a sizeable raise for a group of mainly female workers; in this sense, collective resignation challenged established forms of gendering.

However, we argue that collective action is an open-ended articulation that creates its own conditions. In this case, emphasis on gender equality gave way to a different set of concerns that in turn informed subsequent stages in the articulation of collective action. The politicization of caring replaced gender equality - a shift accompanied by an emphasis on the almost unshakable docility of nurses. Although the gender-reproducing and gender-challenging aspects of politicization in general (Briskin, 2013) are not our main concern here, we call attention to this trade-off between politicization and gender-equality rhetoric, whereby activists adopted an ethic and rhetoric of care as they retreated from formulating interests and demands in terms of gender equality. Thus activists retreated to familiar ground, deploying arguments used in official union campaigns; this might be conceptualized as realigning movement goals with an established gender frame (Einwohner et al., 2000). The individualized nature of this form of action is important here. Activists did not push their views onto the collective; rather, they accommodated the views circulating among the ward nurses, trying to find common denominators. As a neoliberal form of action, collective resignations will not always promote the cultural transformations associated with rank-and-file strikes (Fantasia, 1988); such transformation would likely require that coordination of individual decisions gives way to a properly collective decision-making process. The collective resignation sometimes evolves into a properly collective act, although here it did not.

Revisiting the question raised at the outset - what latitude is there for collective action in neoliberal austerity regimes? - the emerging field of commodified health care and the Swedish industrial relations system do afford certain structures of opportunity, which at the same time narrow the exercise of agency: collective resignation emerges as the only conceivable form of opposition to austerity by Swedish nurses at the workplace level. Hence, on the one hand, this analysis testifies to opportunities opened by the nursing shortage and by austerity regimes in conditions of commodified health 
care. On the other hand, our analysis also highlights the constraints that go along with these same opportunities. An act of collective resignation was carried out by a group of structurally empowered (Silver, 2003) nurses against what they saw as deteriorating working conditions; however, structural power did not, by default, translate into a mode of collective identity that challenged austerity, nor established forms of gendering. For this to take place, our analysis suggests, activists must successfully frame conflict in such ways. Our study also suggests that recent transformations in healthcare organization may, instead, stimulate localist and individualist modes of worker subjectivity. This may pose an obstacle to the development of generalized resistance to austerity.

Will collective resignations become a lever of gender equality? Our analysis indicates that this hinges on nurses' ability to transcend the individualizing thrust of neoliberal forms of agency; in this particular case, gender equality faded out as the stage of properly collective mobilization ended. The efficacy of collective action seems to depend on the emergence and transformation of collectivity; feminist struggles for gender equality are likewise untenable unless they involve transformations of collectivity.

\section{References}

Granberg, M. (2014) Manufacturing dissent: labor conflict, care work, and the politicization of caring. Nordic Journal of Working Life Studies, 4,1, 139-52.

Granberg, M. (2016). Care in Revolt: Labor Conflict, Gender, Neoliberalism. Sundsvall: Mid Sweden University.

Bessant, J. (1992) 'Good women and good nurses': conflicting identities in the Victorian nurses strikes, 1985-6. Labour History, 63, 155-73.

Biggs, M. (2003) Positive feedback in collective mobilization: the American strike wave of 1886. Theory and Society, $32,2,217-54$.

Bohm, E. (1961) Okänd, Gödkänd, Legitimerad: Svensk Sjuksköterskeförenings Första Femtio År. Stockholm: Svensk Sjuksköterskeförening.

Bordogna, L. and Cella, P. (2002) Decline or transformation? Change in industrial conflict and its challenges. Transfer, 8,4, 585-607.

Briskin, L. (2007a) Gendering labour militancies. Paper presented at the Gender as Social Practice Stream of the Gender, Work and Organization Conference, Keele University, June.

Briskin, L. (2007b) Public sector militancy, feminization, and employer aggression: trends in strikes, lockouts, and wildcats in Canada from 1960 to 2004. In Van der Velden, S., Dribbusch, H., Lyddon, D. and Vandaele, K. (eds) Strikes around the World: Case Studies of 15 Countries, pp. 86-113. Amsterdam: Aksant.

Briskin, L. (2013) Nurse militancy and strike action. Workers of the World: International Journal of Strikes and Social Conflicts, 1,2, 105-34.

Brown, G., Greany, A.-M., Kelly-Fitzgibbon, M. and McCarthy, J. (2006) The 1999 Irish nurses' strike: nursing versions of the strike and self-identity in a general hospital. Journal of Advanced Nursing, 56,2, 200-8.

Colatrella, S. (2011) In our hands is placed a power: austerity, worldwide strike wave, and the crisis of global governance. Socialism and Democracy, 25,3, 82-106.

Einwohner, R., Hollander, J. and Olson, T. (2000) Engendering social movements: cultural images and movement dynamics. Gender and Society, 14,5, 679-99.

Eisenstein, H. (2009) Feminism Seduced: How Global Elites Use Women's Labor and Ideas to Exploit the World. Boulder, CO: Paradigm.

Emmel, N. (2013) Sampling and Choosing Cases in Qualitative Research: a Realist Approach. London: Sage.

Fantasia, R. (1988) Cultures of Solidarity: Consciousness, Action and Contemporary American Workers. Berkeley and Los Angeles, CA: University of California Press.

Fransson, S. and Thörnqvist, C. (2003) Gender-specific strategies for industrial action: the Swedish case in historical perspective. In Fleming, D. and Thörnqvist, C. (eds) Nordic Management-labour Relations and Internationalization: Converging and Diverging Tendencies, pp. 193-214. Copenhagen: Nordic Council of Ministers.

Franzway, S. and Fonow, M.M. (2011) Making Feminist Politics: Transnational Alliances between Women and Labor. Champaign, IL: University of Illinois Press.

Fraser, N. (2009) Feminism coopted. New Left Review, 56, 97-118.

Gall, G. (2012) Quiescence continued? Recent strike activity in nine western European economies. Economic and Industrial Democracy, 34,4, 667-91.

Gordon, S. and Nelson, S. (2006) Moving beyond the virtue script in nursing: creating a knowledge-based identity for nurses. In Nelson, S. and Gordon, S. (eds) The Complexities of Care: Nursing Reconsidered, pp. 13-29. Ithaca, NY: Cornell University Press.

Hegel, G.W.F. (2010) The Science of Logic. Cambridge: Cambridge University Press. 
Henttonen, E., LaPointe, K., Pesonen, S. and Vanhala, S. (2013) A stain on the white uniform: the discursive construction of nurses' industrial action in the media. Gender, Work and Organization, 20,1, 56-70.

Hertting, A., Nilsson, K., Theorell, T. and Larsson, U.S. (2004) Downsizing and reorganization: demands, challenges and ambiguity for registered nurses. Journal of Advanced Nursing, 45,2, 145-54.

Hertting, A., Nilsson, K., Theorell, T. and Larsson, U.S. (2005) Assistant nurses in the Swedish healthcare sector during the 1990s: a hard-hit occupational group with a tough job. Scandinavian Journal of Public Health, 33,2, 107-13.

Kavendy, C.M. (1999) Commodifying the polyvalent good of health care. Journal of Medicine and Philosophy, 24,3, 207-23.

Kelly, J. (1998) Rethinking Industrial Relations: Mobilization, Collectivism and Long Waves. New York: Routledge.

Korpi, W. (1981) Unofficial strikes in Sweden. British Journal of Industrial Relations, 9,1, 66-86.

Larsson, B., Letell, M. and Thörn, H. (eds) (2012) Transformations of the Swedish Welfare State: from Social Engineering to Governance? New York: Palgrave Macmillan.

McRobbie, A. (2009) The Aftermath of Feminism: Gender, Culture and Social Change. London: Sage.

Newman, J. (2012) Working the Spaces of Power: Activism, Neoliberalism and Gendered Labour. London: Bloomsbury Academic.

Oulton, J.A. (2006) The global nursing shortage: an overview of issues and actions. Policy, Politics and Nursing Practice, 7,3 (Suppl.), 34-9.

Riessman, K.C. (2002) Analysis of personal narratives. In Gubrium, J.F. and Holstein, J.A. (eds) Handbook of Interview Research, pp. 695-710. London: Sage.

Riessman, K.C. (2008) Narrative Methods for the Human Sciences. London: Sage.

Schmitz, E. (2007) Systerskap som Politisk Handling: Kvinnors Organisering i Sverige 1968 till 1982 (Sisterhood as Political Action: Women's Organizations in Sweden, 1968-1982). Lund: Lund Dissertations in Sociology.

Selberg, R. (2012) Femininity at Work: Gender, Labour, and Changing Relations of Power in a Swedish Hospital. Lund: Arkiv.

Silver, B. (2003) Forces of Labor: Labor Movements and Globalization since 1870. Cambridge: Cambridge University Press.

Thörnqvist, C. (1994) Arbetarna Lämnar Fabriken: Strejkrörelser i Sverige under Efterkrigstiden: deras Bakgrund, Förlopp och Följder (The Workers Leave the Factory: Post-war Strike Movements in Sweden, their Backgrounds, Development and Consequences). Gothenburg: University of Gothenburg.

Walby, S. (2011) The Future of Feminism. Cambridge: Polity Press.

Williams, C.L. (1992) The glass escalator: hidden advantages for men in the 'female' professions. Social Problems, $39,3,253-67$.

\section{Biographical notes}

Magnus Granberg is a lecturer in sociology at the Department of Social Science at the Mid Sweden University. He recently completed a PhD thesis, Care in Revolt, on collective resignations by nurses in Sweden. His research interests include labour conflict and associated transformations in subjectivity.

Katarina Giritli Nygren is Associate Professor in Sociology and the Director of the Forum for Gender Studies, Mid Sweden University. Her research addresses different forms of governance relationships with a focus on processes of inclusion and exclusion in terms of gender, class and ethnicity. One of her recent publications is Challenging the Myth of Gender Equality in Sweden, coedited with Lena Martinsson and Gabrielle Griffin. 